\title{
USO DE MODELAGENS ESPACIAIS PARA ANÁLISE DE RISCO A INCÊNDIO: ANÁLISE PRELIMINAR PARA A REGIÃO NORTE DE GOIÁS
}

\author{
Matheus Bleza Santos ${ }^{(a)}$, Karla Maria Silva de Faria ${ }^{(b)}$ \\ (a) Bolsitsta PIBIC. Instituto de Estudos Sócio Ambientais, Universidade Federal de Goiás, \\ matheus.blesa@gmail.com \\ (b) ) Instituto de Estudos Sócio Ambientais, Universidade Federal de Goiás, karla_faria@ufg.br
}

Eixo: GEOTECNOLOGIAS E MODELAGEM ESPACIAL EM GEOGRAFIA FÍSICA

\section{Resumo}

O uso de Sistemas de informações geográficas otimiza modelagens preditivas de processos naturais ou induzidos por ações antrópicas. O objetivo do trabalho foi o avaliar o risco de incêndios na região norte do estado de Goiás, que apresenta as manchas mais continuas e expressivas de vegetação remanescente do Bioma Cerrado. Utilizando-se de avaliação multicriterial foram selecionadas para a modelagem variáveis como: orientação das encostas, focos de queimadas e estradas que foram ponderados e integrados resultando no mapa de risco de incêndio, zoneado para em cinco classes. Os resultados preliminares indicam que as estradas e suas diferentes tipologias, associadas com encostas com orientação especifica conduziram a indicação de alto de risco e que se faz necessário testar o modelo com dados de uso do solo.

Palavras chave: SIG, análise multicriterial, Cerrado.

\section{Introdução}

Diversos fatores podem ser utilizados para a definição de áreas de risco a incêndios e o uso das tecnologias Sistema de Informações Geográficas (SIG) e de processamento de dados têm se tornado aliados ao planejamento de políticas e estudos que visam a preservação do ambiente. Trabalhos desenvolvidos por Vettorazzi (2007); Tedim e Carvalho (2012); Faria et al., (2014) vão de acordo com essa linha de análise.

O Bioma Cerrado a partir das décadas de 1960 e 1970 sofreu fortes alterações em sua área nativa com o avanço da política denominada de "Marcha para Oeste" e a própria criação da EMBRAPA, que visualizava um melhor aproveitamento de terras e uma melhor qualidade dos grãos, vinculado à chamada Revolução Verde. Nesse contexto, as políticas governamentais trouxeram incremento econômico à região central do país, porém, com a rápida expansão estima-se que $47 \%$ da sua área natural foram alteradas para o uso antrópico (SANO et al, 2007). 
A conversão da vegetação nativa em áreas agrícolas foi promovida por técnicas de desmatamento que envolvia derrubada das espécies de cerrado com técnica de "correntão", cortes rasos, ou queimadas induzidas. As características fenológicas desse bioma favorecem a rápida propagação das queimadas, o que caracteriza tal problemática como um dos maiores problemas para a manutenção e desenvolvimento desse ecossistemas (Ribeiro e Walter, 2008).

Administrativamente essa região é dividida nas microrregiões de Chapada dos Veadeiros, Porangatu, São Miguel do Araguaia e do Vão do Paranã. Conforme dados do IBGE (2010) totalizavam 401.421 habitantes em um total de 39 municípios e uma área territorial de 73.898,26 km². A região destaca-se por apresentar as maiores manchas de cerrado remanescente. $\mathrm{O}$ alvo desta pesquisa destaca apenas as microrregiões de Porangatu, Chapada dos Veadeiros, e Vão do Paranã (Figura 1), que se diferenciam quando ao comportamento do relevo (relevo suave ondulado, fortemente movimentado e plano).

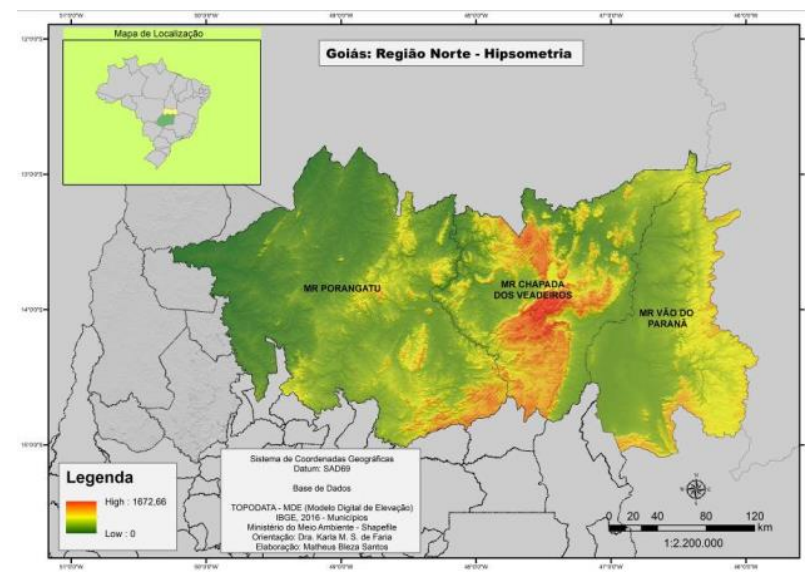

Figura 1 - Mapa de Localização

Nesse sentido o objetivo desse trabalho é a avaliar risco a incêndio nas três micros regiões Chapada, Porangatu e Vão do Paranã, Tal região apresenta dinâmicas interessantes, pois abrigam áreas prioritárias para conservação, diversas categorias de unidade de conservação, áreas internacionalmente prioritárias para conservação (como as reservas das biosferas) e encontram-se entre o eixo de expansão da fronteira agrícola do sentido sul-norte.

\section{Procedimentos metodológicos}

A elaboração do mapa de risco a incêndio adatptou a metodologia proposta por Faria et al., (2014). Assim, foi necessária a elaboração das variáveis referentes: orientação de vertente, estradas/rodovias e focos de queimadas. Tais variáveis e modelagens foram geradas e trabalhadas em ambiente SIG no software ArcGis. 
Um dos produtos do SRTM (Shuttle Radar Topography Mission) que foi utilizado nessa pesquisa referese ao Modelo Numérico do Terreno (MDT). Este modelo possibilitou a avaliação da orientação dasvertente e correlação com as condições de suscetibilidade à exposição do sol e consequentemente a maior disponibilidade energética para a redução da umidade do material combustível (Pezzopane et al., 2001).

Os focos de queimadas foram obtidos na base de dados do programa de Queimadas do Instituto de Pesquisas Espaciais (INPE) considerando o período de 2 meses entre Junho e Agosto de 2016, obtidos através dos satélites NOAA, GOES, AQUA, TERRA e METEOSAT. Aplicou-se análise da densidade de kernel em tais dados. A densidade kernel calcula com base na amostragem pontual um raio de influência aplicando função matemática de 1, na posição do ponto, a 0, na fronteira da vizinhança (Silverman,1986). A base de dados referente a estradas e rodovias foi obtida na Agência Goiana de Transportes e Obras (AGETOP); para tais dados foram definidos buffers (Quadro 1) com intuito de ponderar a proximidade e influência das estradas ao risco a incêndio (VETTORAZZI, 1998).

Quadro 1 - Buffers definidos para a area de estudo

\begin{tabular}{|l|l|}
\hline \multicolumn{1}{|c|}{ Situação } & \multicolumn{1}{|c|}{ Distância Buffer (m) } \\
\hline Não Pavimentada & 100 metros \\
\hline Pavimentada & 150 metros \\
\hline Pavimentada - Dupla & 200 metros \\
\hline Em construção & 50 metros \\
\hline Outras Estradas & 50 metros \\
\hline Planejada & Sem buffer \\
\hline
\end{tabular}

Esses buffers visam dar maior grau de distância a categorias que possuem uma importância maior a concentração de queimas, sendo atribuídos esses valores pela sentença de importância.

O método de Análise Multicriterial implementados em ambiente SIG para avaliação do risco foi o Processo Hierárquico Analítico (AHP) (SAATY (2008), as variáveis foram julgadas e ponderadas por esse método, sendo estabelecida a equação Equação $\mathrm{ARI}=[(0,13 \times$ Orientação $)+(0,12 \times$ Estradas $)+(0,18 \times$ Focos de Queimadas)], que foi processada pelo Raster Calcutator da extensão Spatial Analyst do ArcGis. O mapa resultante foi reclassificado em cinco níveis, que correspondem as classes: baixo, moderado e alto, muito alto e extremo.

\section{Resultados e Discussões}




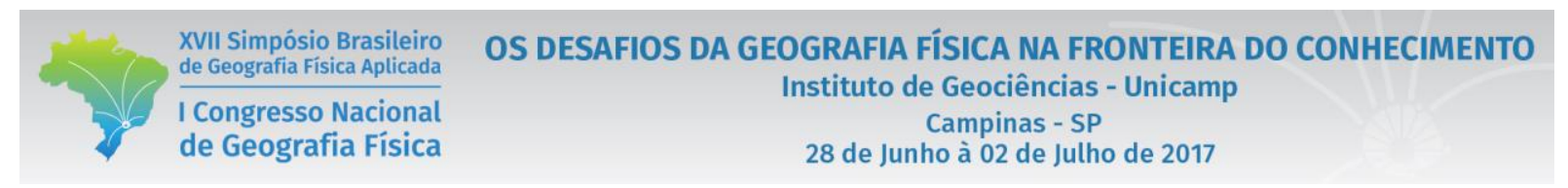

A avaliação das queimadas em ambientes de cerrado é polêmica e complexa, pois se trata de um fenomeno associado aos processos ecológicos do cerrado, mas aos quais se associam impactos não mitigáveis e que diretamente afetam a biodiversidade.

O resultado da avaliação multicriterial ao risco a incêndios (Figura 2) segundo a metodologia apresentada indica que as áreas classificadas com alta probabilidade a incêndios (classes Muito Alta e Extrema) se localizam nas porções leste (MR Vão do Paranã) e Oeste (MR Porangatu). Tais localidades concentram encostas com orientação para Norte e Leste, que estão mais expostas a insolação no período de estiagem e apresentam ainda proximidade com estradas/rodovias pavimentadas.

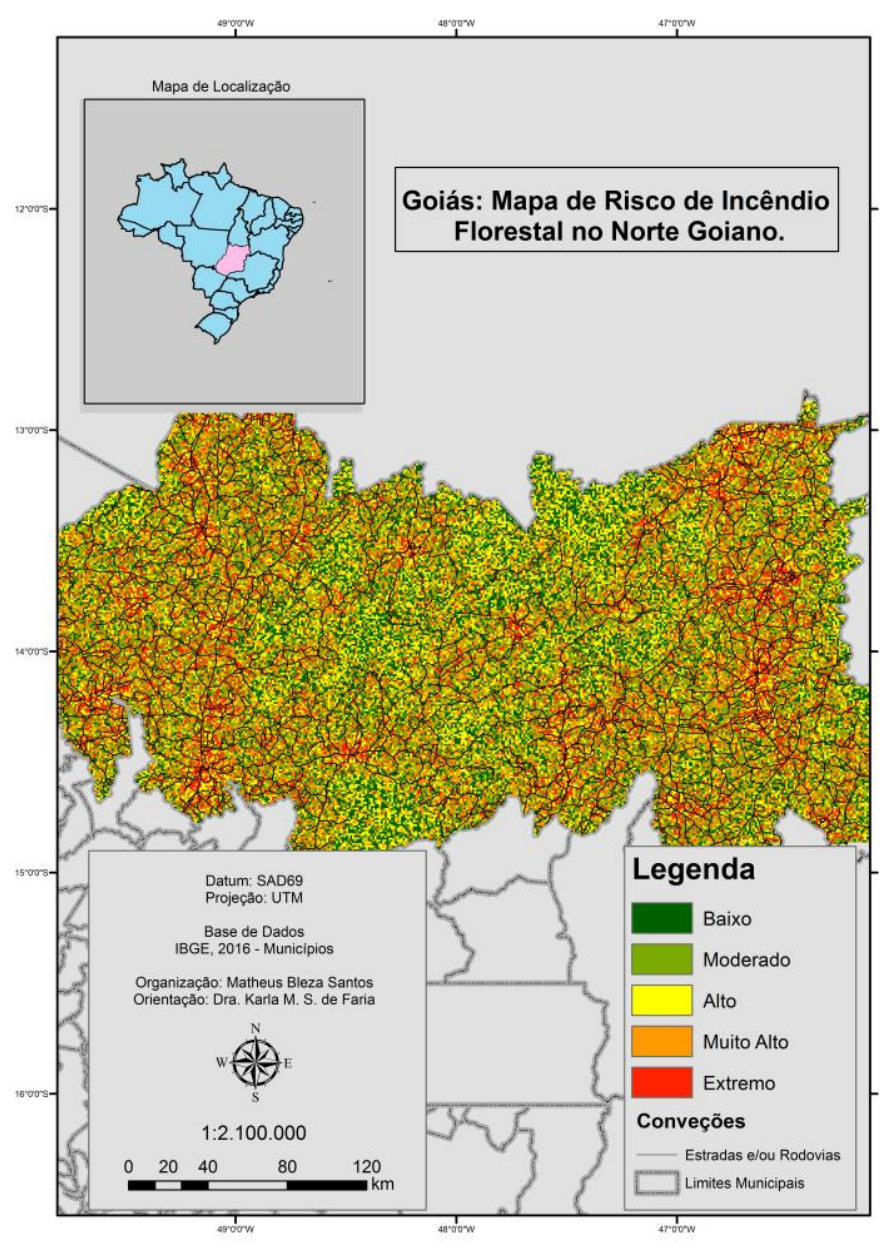

Figura 2 - Mapa Preliminar de risco a incêdios.

A porção central da região, que corresponde a parte da MR Porangatu e a MR Chapada destaca-se por apresentar baixo indicativo de risco a incêndios. Em tal localidade mesmo encostas com orientação de face para norte e/ou leste não foram classificadas como de alta suscetibilidade, pois existe baixa 
disponibilidade de estradas pavimentadas. Havendo assim a formação de "ilhas" de proteção como na porção do extremo sul da MR Porangatu, onde não se verificou a presença de estradas, sendo assim, menos propensa a incêndios. Além disso, há uma forte correlação entre concentração de estradas/rodovias e áreas com altos riscos a incêndio, como se pode observar na MR Vão do Paranã concentrando rodovias como a GO-110 juntamente com a GO-108 que dão acesso, por exemplo, ao Parque Estadual da Terra Ronca.

\section{Considerações finais}

O uso do SIG favorece modelagens para análise e identificação das localidades de maiores riscos a incêndios, possibilitando, indicação das áreas prioritárias para ações de combate e minimização. O modelo apresentado nesse artigo ainda é preliminar, fazendo-se necessário avaliar condições de uso da terra e fitofisionomias de cerrado e qualificar o quanto as estradas influenciam como peso no modelo, validando os dados com informações disponibilizadas por instituições de pesquisa. Apesar disso, foi possível verificar um entrelaçamento de dados onde as estradas junto com orientação da vertente e os focos, atrelado a outras variáveis possibilitam ajuda a tomada de decisão que vai no sentido de proteger áreas mais sensíveis.

\section{Bibliografia}

FARIA, K. M. S de; SANTOS, R. A. ; SOARES NETO, G. B. . Avaliação multicriterial com Sistemas de Informações Geográficas ao risco de incêndios na Reserva da Biosfera do Bioma Cerrado. In: VIII Simpósio Latino Americano de Geografia Física Aplicada, 2014, Santiago. Anais do VIII Simpósio Latino Americano de Geografia Física Aplicada, 2014. v. 1.

PEZZOPANE, J. E. M.; OLIVEIRA NETO, S.N.; VILELA, M. F. Risco de incêndios em função da característica do clima, relevo e cobertura do solo. Floresta e Ambiente, 8 (1),161-165. 2001

RIBEIRO, J.F. \& WALTER, B.M.T.. As principais fitofisionomias do Bioma Cerrado. In Cerrado: ecologia e flora (S.M. Sano, S.P. Almeida \& J.F. Ribeiro, eds.). Embrapa Cerrados, Planaltina. p.151 -212. 2008

$\mathrm{S}$

AATY, T. Decision making with the analytic hierarchy process. Int. J. Services Sciences, 1(1). 2008

SANO, E. E. ; ROSA, R. ; BRITO, J. L. ; FERREIRA JR, L. G. . Mapeamento de cobertura vegetal do bioma

Cerrado: estratégias e resultados. Planaltina: Embrapa Cerrados, 2007 (Boletim de Pesquisa).

SILVERMAN, B. W. Density Estimation for Statistics and Data Analysis. Nova York: Chapman and Hall,1986.

TEDIM, F.; CARVALHO, S. A vulnerabilidade aos incêndios florestais: reflexões em torno de aspectos conceptuais e metodológicos. Territorium, 20,85-99. 2013

VETORAZZI, C. A. Avaliação Multicritérios, em ambiente SIG, na Definição de Áreas Prioritárias à restauração florestal visando à conservação de recursos hídricos. 2007. Tese de Livre Docência. (Departamento de Engenharia Rural. Piracicaba. 2007 